\title{
Novel Therapeutic Strategies and Combinations for HER2-Overexpressing Breast Cancer
}

\author{
Sylvia Shabaya and Rita Nahta \\ Emory University, \\ USA
}

\section{Introduction}

Approximately $20-30 \%$ of breast cancers show increased expression of the HER2 receptor tyrosine kinase. Elevated levels of HER2 are associated with aggressive disease, high metastatic potential, and reduced survival versus other breast cancer subtypes (Slamon, 1987). Trastuzumab (Herceptin) is a monoclonal antibody targeted against an extracellular region of HER2 (Carter, 1992). Clinical trials have shown that $15-30 \%$ of patients with HER2overexpressing metastatic breast cancer respond to single-agent trastuzumab for a median duration of approximately 10 months (Baselga, 1996; Cobleigh, 1999). Response rates improve when trastuzumab is combined with chemotherapy in patients with HER2overexpressing metastatic breast cancer (Esteva, 2002; Slamon, 2001). A subset of trastuzumab-resistant breast cancers respond to the dual EGFR/HER2 kinase inhibitor lapatinib, although the majority (70\% or more) show primary resistance (Geyer, 2006). Similar to trastuzumab treatment, clinical trials with lapatinib indicated that the median duration of response to lapatinib in a heavily pre-treated, trastuzumab-refractory population was less than one year (Geyer, 2006). Hence, resistance to clinically available HER2-targeted agents is a major concern in the treatment of patients with HER2overexpressing metastatic breast cancer.

\section{HER2 and breast cancer}

The human epidermal growth factor receptor 2 (HER2) is overexpressed in approximately $25 \%$ of invasive breast carcinomas. HER2 is a member of the epidermal growth factor receptor (EGFR) family, which also contains two other receptors, HER3 and HER4 (Fig. 1). Each of these cell surface receptors has an extracellular ligand-binding domain and a transmembrane-spanning domain (Nielsen, 2008). All HER family receptors except HER2 bind specific ligands that induce conformational changes and receptor homo- or heterodimerization. Several HER family ligands have been identified including transforming growth factor alpha (TGFa), epidermal growth factor (EGF), and the heregulins (Nielsen, 2008). In addition, all except HER3 contain an intracellular tyrosine kinase domain. Receptor dimerization activates the kinase function of receptors, leading to receptor auto- or transphosphorylation. The phosphorylated tyrosine residues serve as docking sites for SH2 and PTB-domain containing proteins, which links the receptors to multiple cell survival and proliferation pathways including the phosphatidylinositol-3 kinase (PI3K) and mitogen- 
activated protein kinase (MAPK) cascades (Spector, 2009; Graus-Porta, 1997). HER2 is the preferred dimerization partner for the other HER family members, as HER2 heterodimers have increased ligand binding affinity and increased catalytic activity relative to other heterodimer complexes (Spector, 2009; Graus-Porta, 1997). In particular, the HER2-HER3 heterodimer has the strongest kinase activity and transforming ability, as HER3 possesses multiple PI3K docking sites in its cytoplasmic tail.

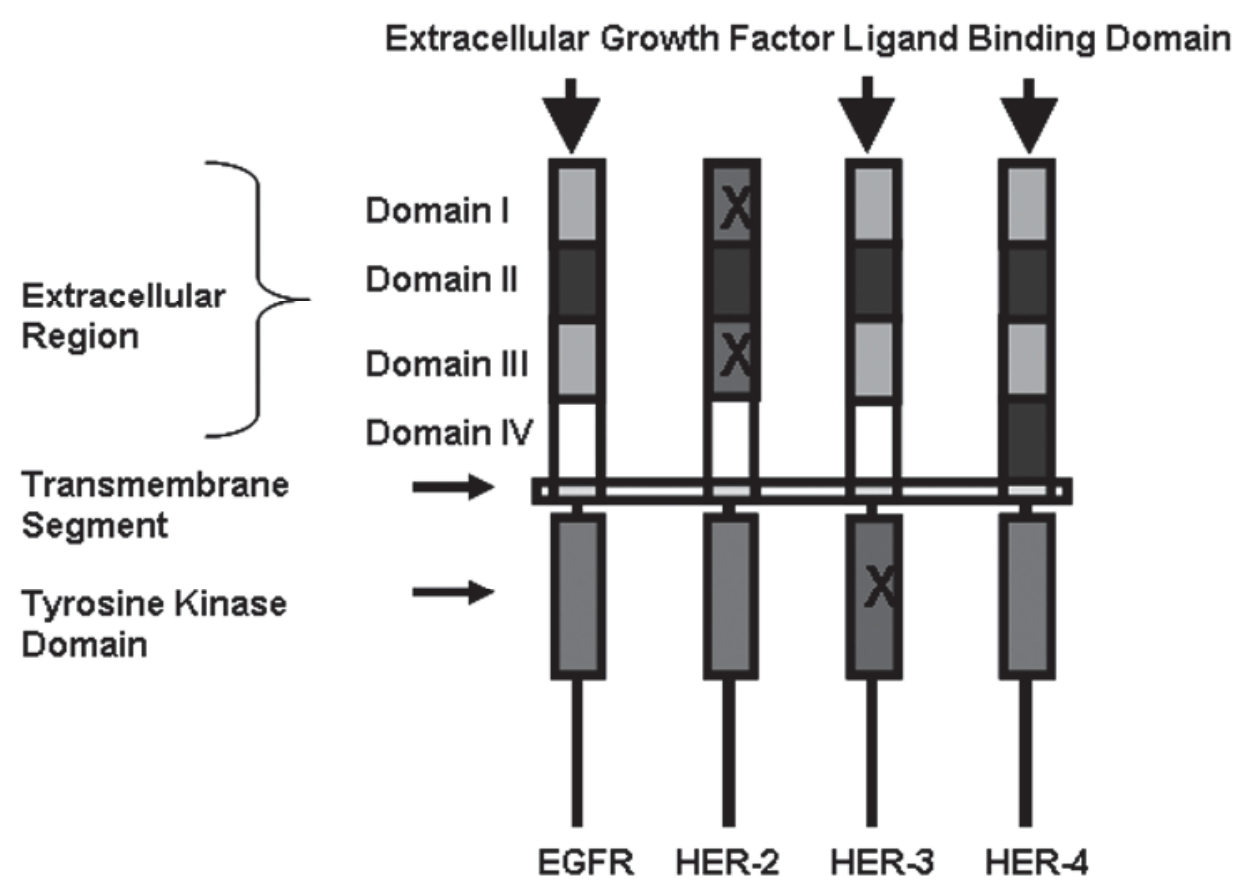

Fig. 1. HER/erbB family of growth factor receptors. The four members of the EGFR family are illustrated. The inactive ligand-binding domains of HER2 and the inactive kinase domain of HER3 are denoted with an X. Trastuzumab binds to domain IV of the extracellular region of HER2.

\subsection{Targeting HER2 in breast cancer}

Patients who are diagnosed with HER2-overexpressing breast cancer have a poor prognosis, and shorter progression-free and overall survival compared to patients with other subtypes of breast cancer (Eccles, 2001). HER2-overexpressing tumors have been found to be larger in size, and higher in nuclear grade, S phase fraction, and aneuploidy (Nielsen, 2008). Traditional cancer treatments have targeted DNA replication or cell division, leading to nonspecific cytotoxicity (Oakman, 2010). The identification of abnormal signaling from HER2 led to the development of trastuzumab (Herceptin) (Genentech, San Francisco, CA, USA), which is the first drug to target the genetic lesion or oncogenic addiction found in patients with HER2-overexpressing breast cancer. Clinically, trastuzumab was found to significantly enhance the effectiveness of conventional chemotherapies. However, the median duration of response was less than one year, indicating rapid development of 
resistance. The precise mechanism of action of trastuzumab is unclear, but it is thought to involve HER2 downregulation (Cuello, 2001; Gajria, 2011), selective inhibition of HER2HER3 heterodimerization (Junttila, 2009; Gajria, 2011), prevention of HER2 extracellular domain proteolytic cleavage (Molina, 2001; Gajria, 2011), and activation of an immune response including antibody-dependent cellular cytotoxicity (Sliwkowski, 1999). As a single agent, trastuzumab achieved an overall response rate for a median duration of about nine months (Baselga, 1996; Cobleigh, 1999; Nielsen, 2008; Slamon, 2001). The low response rate indicates that many patients with HER2-overexpressing breast cancer have primary resistance to trastuzumab, while the short duration of response indicates rapid development of acquired resistance. Multiple mechanisms contributing to trastuzumab resistance have been proposed, resulting in multiple approaches to potentially treat resistant cancers (Table 1).

\begin{tabular}{|l|l|}
\hline Target & Role in trastuzumab resistance \\
\hline PI3K & $\begin{array}{l}\text { Increased PI3K signaling due to PIK3CA mutations or PTEN loss was reported } \\
\text { in trastuzumab-resistant cancers }\end{array}$ \\
\hline mTOR & $\begin{array}{l}\text { As a downstream molecule of PI3K, mTOR has become a target of inhibition in } \\
\text { resistant cancers; multiple mTOR inhibitors are in advanced phases of clinical } \\
\text { development }\end{array}$ \\
\hline $\begin{array}{l}\text { IGF- } \\
\text { IR }\end{array}$ & $\begin{array}{l}\text { Increased expression of IGF-IR has been shown to reduce response to } \\
\text { trastuzumab; increased IGF-IR overexpression was associated with lower } \\
\text { response to neoadjuvant trastuzumab; IGF-IR/HER2 interaction and crosstalk } \\
\text { were associated with acquired resistance }\end{array}$ \\
\hline Src & $\begin{array}{l}\text { Trastuzumab-mediated inhibition of Src activity appears to be important to its } \\
\text { anti-cancer activity; resistance to trastuzumab was associated with PTEN loss } \\
\text { and increased Src activity; targeting Src with dasatinib or genetic knockdown } \\
\text { blocked growth of resistant cancers }\end{array}$ \\
\hline Cdk2 & $\begin{array}{l}\text { Reduced p27kip1 levels or amplification of cyclin E gene have been reported to } \\
\text { result in increased cdk2 activity in trastuzumab-resistant cancers }\end{array}$ \\
\hline
\end{tabular}

Table 1. Potential pharmacologic targets in trastuzumab-resistant HER2-positive breast cancers.

\section{Targeting PI3K/mTOR signaling in HER2-overexpressing breast cancer}

HER2 signaling is initiated upon receptor dimerization, which induces phosphorylation of tyrosine residues within the receptor cytoplasmic domain. The phosphorylated residues serve as docking sites for adaptor proteins and link the receptor to downstream survival pathways including the PI3K/Akt/mTOR axis (Spector, 2009). The PI3K pathway is frequently hyper-activated in many cancers. An association between oncogenic PI3K mutations and trastuzumab resistance was found in a study examining HER2overexpressing tumors from patients with trastuzumab-refractory disease (Berns, 2007). About $25 \%$ of tumors analyzed had PIK3CA mutations, and reduced phosphatase and tensin homolog (PTEN) expression was present in $22 \%$ of the tumors. Immunohistochemistry studies performed in a retrospective analysis of HER2-amplified breast tumors treated with trastuzumab plus taxanes showed a postive correlation between PTEN down-regulation and tumor response (Nagata, 2004). To evaluate the role of PI3K 
post-trastuzumab exposure, tumors that had progressed on trastuzumab were analyzed for changes in PI3K signaling. The findings demonstrated that PI3K mutations and PTEN loss were identified in patients who had initially responded to trastuzumab; reduced PTEN expression was identified in tumors that had developed trastuzumab resistance, but had not been identified before trastuzumab treatment. This finding indicates that PI3K mutations can occur as a result of trastuzumab treatment in some tumors (Kalinsky, 2009; Sakr, 2010; Gajria, 2011). Thus, there is ample rationale for co-targeting PI3K and HER2 in breast cancer. Activated Akt regulates several downstream signaling molecules including mTOR, a highly conserved $289-\mathrm{kDa}$ serine/threonine kinase that plays roles in cell proliferation, survival, and motility (Lang, 2010). mTOR activation is initiated when phosphorylated PI3K/Akt inhibits the TSC1/TSC2 complexes, thereby preventing Rheb from inhibiting mTOR. mTORC1 (mTOR, Raptor, mLST8/GBL and PRAS40) and mTORC2 (mTOR, RICTOR, mLST8/GBL, SIN1, and PROTOR/PRR5) are the two distinct complexes through which mTOR exerts cellular effects. The complexes have different functional roles, with mTORC1 having been implicated in cell cycle progression, motility, and protein biosynthesis, while mTORC2 regulates cytoskeleton organization, and regulates cell growth and survival (Wullschleger, 2005; Van der Heijen, 2011).

Preclinical in vivo studies in which mice were treated with single agent trastuzumab, the mTOR inhibitor rapamycin, or a combination of trastuzumab plus rapamycin showed that the combination was more effective at inducing tumor regression than either of the single agent treatments (Miller, 2009). In cell culture experiments using the rapamycin analogue RAD001, a greater amount of growth inhibition was observed with combination mTOR inhibition plus HER2-targeting than with either drug alone. Trastuzumab partially decreased PI3K activity, but not mTOR activity (Miller, 2009). Increased PI3K signaling is a validated mechanism of trastuzumab resistance, but its association with lapatinib resistance is yet to be determined due to conflicting data (Eichhorn, 2008; O'Brien, 2010). Patients with HER2-overexpressing breast cancer who have developed resistance to trastuzumab may be given the dual EGFR/HER2 tyrosine kinase inhibitor lapatinib. Response to single agent lapatinib is less than $25 \%$, indicating cross-resistance between trastuzumab and lapatinib (Blackwell, 2010; Eichhorn, 2008). As with trastuzumab treatment, the small subset of patients who initially responded to lapatinib eventually developed resistance, at which point there is no standard therapeutic approach available. Phase I trials have indicated that in patients with trastuzumab-resistant, heavily pretreated breast cancer, combined everolimus plus trastuzumab could be a promising treatment (Jerusalem, 2011). It is thought that the inability of trastuzumab to completely inhibit PI3K/Akt/mTOR signaling may permit escape from growth inhibition; mTOR inhibitors would thus synergize with trastuzumab to prevent the continued growth of HER2-dependent cancer cells.

In contrast to PI3K, very little has been published regarding the role of MAPK signaling in trastuzumab resistance. Our data suggests that phosphorylation of Erk1/2, which is a marker of MAPK activity, is not increased in resistant cells (Fig. 2A). Inhibition of MEK (upstream of Erk1/2) using a small molecule MEK kinase inhibitor called PD0325901 reduces p-Erk1/2 levels in parental HER2-overexpressing breast cancer cells and in acquired trastuzumab-resistant and primary trastuzumab-resistant cells (Fig. 2B). However, trastuzumab-naïve and trastuzumab-resistant cells are relatively resistant to PD0325901, in that doses up to $10 \mathrm{uM}$ do not block proliferation of HER2-overexpressing trastuzumabnaïve or resistant cells (Fig. 2C). Thus, our data indicate that MAPK signaling may not be a major mechanism of trastuzumab resistance. 
A

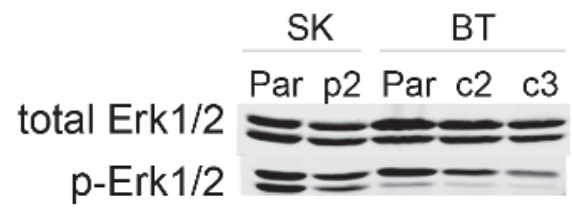

B



C

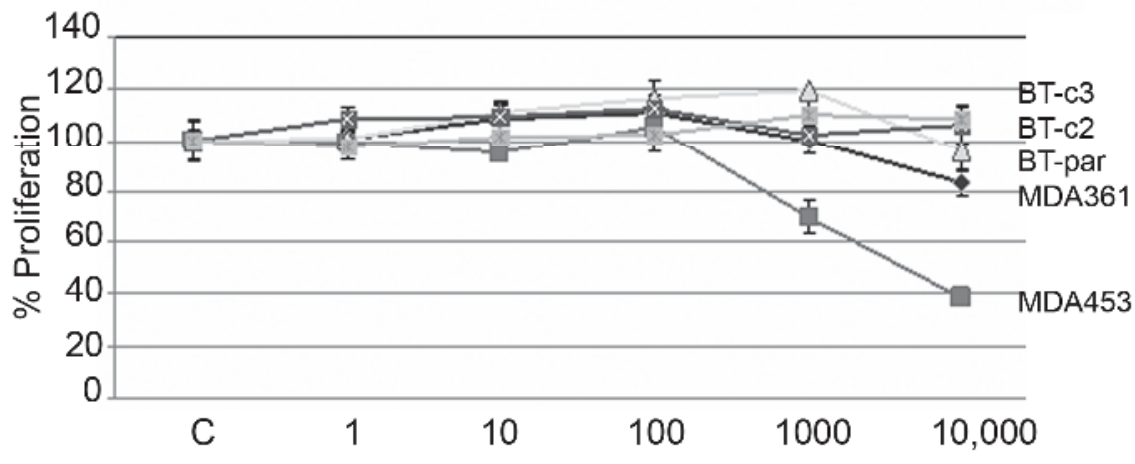

MEK inhibitor (nM)

Fig. 2. Role of MAPK signaling in trastuzumab-resistant cells. (A) SKBR3 parental, trastuzumab-resistant pool 2, and BT474 parental, and trastuzumab-resistant clone 2 and clone 3 cells were Western blotted for phosphorylated and total Erk1/2. (B) BT-parental, BTc2 (resistant clone 2), and MDA-MB-361 primary trastuzumab-resistant cells were treated with MEK inhibitor PD0325901 at 10, 100, or 1000nM for 6 hours or with DMSO control (C) corresponding to the volume found in the highest dose of PD0325901. Total protein lysates were Western blotted for phosphorylated and total Erk1/2. (C) BT-parental, resistant clone 2 and 3, MDA361, and MDA453 cells were treated with MEK inhibitor PD0325901 at 1, 10, 100,1000 , or 10, 000nM for 48 hours with six replicates per treatment group. Control cells were treated with DMSO corresponding to the volume found in the highest dose of PD0325901. Proliferation was assessed by MTS assay, and is shown as a percentage of control group per line.

\section{Targeting IGF-IR signaling in HER2-overexpressing breast cancer}

The insulin-like growth factor receptor I (IGF-IR) is a heterotrimeric transmembrane tyrosine kinase receptor that regulates cell metabolism and growth (Chaves, 2010), and has 
been associated with increased risk and maintenance of multiple cancers including HER2overexpressing breast cancer (Esparis-Ogando, 2008; Hankinson, 1998; Surmacz, 2000). Circulating ligands of the insulin-like growth factor (IGF) system include IGF-I and IGF-II, with IGF-I having the highest affinity for IGF-IR. Upon binding to IGF-IR, a receptor conformational change is induced that leads to tyrosine phosphorylation and activation of several downstream survival signaling pathways such as the Ras/Raf/mitogen activated protein kinase pathway (MAPK), and the PI3K/Akt/mTOR pathway. Activation of these pathways results in cell cycle progression and resistance to apoptosis (Chaves, 2011; Adams, 2000). The IGF binding proteins (IGFBPs) modulate IGF-IR activity by binding to the IGF ligands thereby sequestering them and preventing ligand-induced receptor activation (Adams, 2000). Higher levels of circulating IGF-I have been linked to trastuzumab resistance in HER2-overexpressing breast cancer, with the addition of IGFBP3 decreasing IGF-IR activity, and subsequently resulting in an increased response to trastuzumab ( $\mathrm{Lu}, 2001$; Jerome, 2006).

We found by gene microarray analysis that IGFBP3 and IGFBP5 were down-regulated in resistant versus sensitive cells (Table 2). However, ELISA of secreted IGFBP3 (Fig. 3A) or real-time PCR analysis of endogenous IGFBP3 or IGFBP5 transcript level (Fig. 3B) failed to show any differences in IGFBP3 or IGFBP5 level in resistant versus parental cells. Thus, our data do not support down-regulation of IGFBP3 or IGFBP5 as a mechanism of increased IGF-IR signaling in trastuzumab resistance.

\begin{tabular}{|c|c|c|c|}
\hline $\begin{array}{l}\text { Gene } \\
\text { Name }\end{array}$ & Fold Change & ILMN_GENE & DEFINITION \\
\hline IGFBP5 & -20.55848937 & IGFBP5 & $\begin{array}{l}\text { Homo sapiens insulin-like growth factor binding protein } \\
5 \text { (IGFBP5), mRNA. }\end{array}$ \\
\hline IGFBP5 & -20.0185274 & IGFBP5 & $\begin{array}{l}\text { Homo sapiens insulin-like growth factor binding protein } \\
5 \text { (IGFBP5), mRNA. }\end{array}$ \\
\hline IGFBP3 & -7.77282369 & IGFBP3 & $\begin{array}{l}\text { Homo sapiens insulin-like growth factor binding protein } \\
3 \text { (IGFBP3), transcript variant } 2 \text {, mRNA. }\end{array}$ \\
\hline PKIA & -6.484521044 & PKIA & $\begin{array}{l}\text { Homo sapiens protein kinase (cAMP-dependent, } \\
\text { catalytic) inhibitor alpha (PKIA), transcript variant } 7, \\
\text { mRNA. }\end{array}$ \\
\hline IGFBP3 & -6.193624741 & IGFBP3 & $\begin{array}{l}\text { Homo sapiens insulin-like growth factor binding protein } \\
3 \text { (IGFBP3), transcript variant } 1 \text {, mRNA. }\end{array}$ \\
\hline PKIA & -5.371909749 & PKIA & $\begin{array}{l}\text { Homo sapiens protein kinase (cAMP-dependent, } \\
\text { catalytic) inhibitor alpha (PKIA), transcript variant 6, } \\
\text { mRNA. }\end{array}$ \\
\hline BASP1 & -4.444496135 & BASP1 & $\begin{array}{l}\text { Homo sapiens brain abundant, membrane attached } \\
\text { signal protein } 1 \text { (BASP1), mRNA. }\end{array}$ \\
\hline HERC6 & -4.048474978 & HERC6 & Homo sapiens hect domain and RLD 6 (HERC6), mRNA \\
\hline FRAS1 & -3.988854857 & FRAS1 & Homo sapiens Fraser syndrome 1 (FRAS1), mRNA. \\
\hline THBS1 & -3.966312615 & THBS1 & Homo sapiens thrombospondin 1 (THBS1), mRNA. \\
\hline
\end{tabular}

Table 2. Genes that are down-regulated in SKBR3- and BT474-derived acquired trastuzumab-resistant cells versus parental SKBR3 and BT474 cells by 4-fold or more. 
A

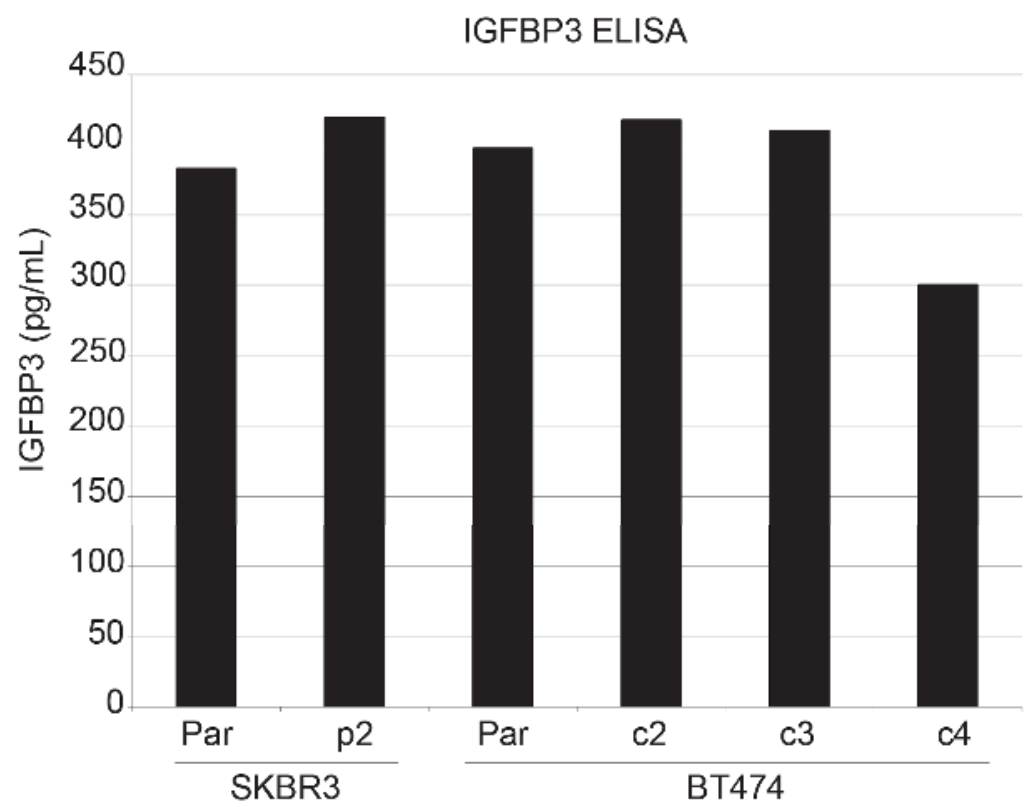

B
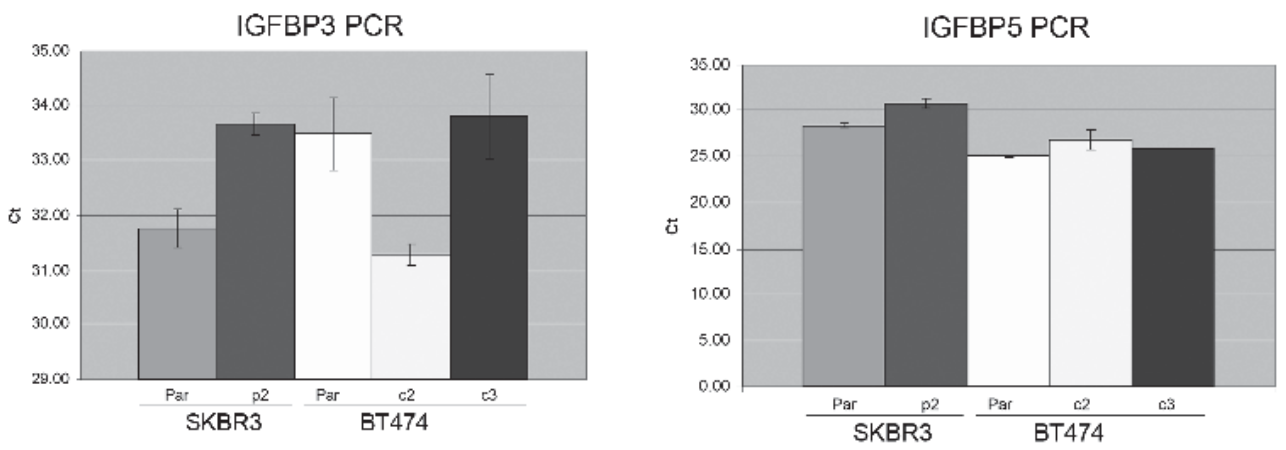

Fig. 3. IGFBP3 and IGFBP5 in resistant and sensitive cells. (A) Secreted IGFBP3 was assessed by ELISA in SKBR3 parental, resistant pool 2, BT474 parental, resistant clone 2 and clone 3 cells. IGFBP3 is shown in $\mathrm{pg} / \mathrm{mL}$ and was measured in triplicate with reproducible results per line. (B) Real-time PCR analysis of IGFBP3 and IGFBP5 was examined in triplicate per line, with error bars representing standard deviation between replicates. Housekeeping gene RPLPO was measured as an internal control; IGFBP3 and IGFBP5 values are normalized to RPLPO.

A subset of HER2-/ IGF-IR-overexpressing cells were found to be less sensitive to the growth inhibitory effects of trastuzumab when compared to HER2-overexpressing cells that do not overexpress IGF-IR (Lu, 2001). Flow cytometry revealed that after trastuzumab 
treatment, HER2 overexpressing cells were less likely to progress through the cell cycle and stopped at the G1 phase, while a greater number of HER2/IGF-IR overexpressing cells passed the restriction point and completed the cell cycle. These results demonstrate that IGF-IR interferes with the growth inhibitory actions of trastuzumab, supporting therapeutic strategies that co-target HER2 and IGF-IR. Further, we discovered that signaling interactions exist between IGF-IR and HER2 in trastuzumab-resistant cancers (Nahta, 2005; Jin, 2008). Immunoprecipitation and immunoblotting experiments revealed that IGF-I stimulation results in an increase in IGF-IR phosphorylation more rapidly in trastuzumab-resistant cells than in trastuzumab-sensitive cells. Furthermore, IGF-IR heterodimerization with HER2 results in HER2 activation in trastuzumab-resistant cells, but not in trastuzumab-sensitive cells, indicating crosstalk between the two receptors. Kinase inhibition or antibody blockade of IGF-IR restores trastuzumab sensitivity. Treatment of trastuzumab-resistant breast cancer cells with the highly specific IGF-IR antibody alpha IR3 disrupted the IGF-IR/HER2 heterodimer and increased trastuzumab sensitivity. These results suggest that IGF-IRtargeted treatments may be useful in combination with trastuzumab.

The association of increased IGF-IR activity with the development of trastuzumab resistance in HER2-overexpressing breast cancer makes IGF-IR an important target. Researchers have been working toward the goal of developing agents that target IGF-IR for the past several years with each generation of agents aimed at producing a greater benefit for the patient while decreasing adverse effects. IGF-IR and the insulin receptor (IR) are $60 \%$ homologous, with one of the adverse effects of IGF-IR antibody treatment being downregulation of the IR, leading to hyperglycemia (Sachdev, 2006). In an effort to remedy this problem, pharmacological agents like the small molecule tyrosine kinase inhibitor NVP-AEW541 (Novartis Pharma, Basel Switzerland) are specific for IGF-IR and less likely to interfere with glucose metabolism. Combination treatment with NVP-AEW541 and trastuzumab showed synergistic growth inhibitory effects, indicating that inhibiting IGF-IR plus HER2 could benefit patients whose tumors overexpress both receptors (Esparis-Ogando, 2008).

IGF-IR overexpression and crosstalk with HER2 suggests that IGF-IR plays a crucial role in conferring trastuzumab resistance. The molecular signaling pathways by which IGF-IR confers resistance to trastuzumab is not clear, although downstream focal adhesion kinase (FAK) and PI3K/Akt pathway signaling likely play a role (Yang, 2010). This data linking IGF-IR to the development of trastuzumab resistance, along with the increased sensitivity to trastuzumab upon IGF-IR inhibition provides a rational for the development of combinatorial HER2 and IGF-IR targeting.

\section{Targeting Src in HER2-overexpressing breast cancer}

Trastuzumab treatment of HER2-overexpressing breast cancer cells results in inhibition of Src non-receptor tyrosine kinase (Nagata, 2004). Src inhibition appears to be important to trastuzumab-mediated anti-cancer activity, as increased Src signaling is associated with trastuzumab resistance (Mitra, 2009; Liang, 2010; Zhang, 2011). One mechanism leading to increased Src activity appears to be a variant of HER2 called HER2 delta 16 (Mitra, 2009), which shows increased oncogenic activity. Local disease progression involved HER2Delta16 in $89 \%$ of breast cancer patients with HER2-positive tumors (Mitra, 2009). Transfection of MCF7 or NIH3T3 cells with HER2 delta 16 promoted receptor dimerization, invasion, and trastuzumab resistance (Mitra, 2009). The oncogenic properties of HER2Delta16 were mediated through direct interaction of HER2Delta16 with Src kinase. Activated Src kinase 
was found in $44 \%$ of HER2Delta16-positive breast carcinomas (Mitra, 2009). Dual targeting of HER2Delta16 plus Src with dasatinib resulted in Src inactivation, destabilization of HER2Delta16, and decreased tumorigenicity (Mitra, 2009). In addition, Src activation via Jak2 has been shown to reduce trastuzumab activity (Liang, 2010). Recombinant human erythropoietin activated Jak2-Src signaling and inactivated PTEN in HER2-positive cells (Liang, 2010). Combined treatment with recombinant human erythropoietin plus trastuzumab reduced response to trastuzumab in cell culture and in vivo models. Further, shorter progression-free and overall survival was found in patients with HER2-positive breast cancer treated concurrently with erythropoietin and trastuzumab (Liang, 2010). Src was also shown to be activated in primary and acquired trastuzumab resistance as a consequence of PTEN loss (Zhang, 2011). Src-targeted therapy blocked growth of trastuzumab-resistant tumors in vivo (Zhang, 2011). Thus, Src activation may occur via multiple mechanisms, ultimately abrogating sensitivity to trastuzumab. Combining Srctargeted therapy with trastuzumab may offer benefit to patients with HER2-overexpressing breast cancer.

\section{Role of p27 and cdk2 in HER2-overexpressing breast cancer}

Trastuzumab induces G1 arrest by several mechanisms including increased expression of cyclin-dependent kinase inhibitor p27kip1, which inhibits cyclin E/cdk2 and cyclin A/cdk2 complexes and blocks cell cycle progression through S phase (Lane, 2001; Le, 2003). Trastuzumab induces p27kip1expression by suppressing expression of proteins that sequester p27kip1, which also results in increased interaction between p27kip1 and cdk2 leading to cdk2 inactivation (Lane, 2001). We previously reported (Nahta, 2004b) that cells with acquired trastuzumab resistance showed increased proliferation, reduced p27kip1 expression, reduced p27kip1-cdk2 interaction, and increased cdk2 activity relative to parental, trastuzumab-sensitive cells. Transfection of wild-type p27kip1 increased trastuzumab sensitivity in cells with acquired resistance (Nahta, 2004b). Yakes et al. (Yakes, 2002) showed that knockdown of p27kip1 reduced trastuzumab sensitivity in HER2-overexpressing breast cancer cell lines, further supporting a requirement of p27kip1 expression for optimal response to trastuzumab. Post-translational modification of p27kip1 occurs primarily by phosphorylation, with subsequent protein ubiquitination and degradation. Preliminary data supporting ubiquitin-proteasome degradation of p27kip1 as a mechanism of p27kip1 down-regulation in trastuzumab resistance includes our finding that proteasome inhibitor MG132 induced p27 expression and reduced viability of resistant cells (Nahta, 2004b). Further, Cardoso et al. (Cardoso, 2006) showed that proteasome inhibitor bortezomib induced p27kip1 and increased the efficacy of trastuzumab in HER2-overexpressing breast cancer cells. PI3K inhibition has been shown to induce p27kip1 expression, and is believed to contribute to p27kip1 down-regulation and acquired trastuzumab resistance. In addition to observing reduced p27kip1 levels in models of acquired resistance, our data indicates that p27kip1 expression is downregulated post-transcriptionally in cells with primary trastuzumab resistance (Fig. 4). Cyclin E expression has been shown to be regulated by HER2 expression status, in that HER2 knockdown resulted in reduced cyclin E level and reduced cyclin E-associated kinase activity (Mittendorf, 2010). In addition, HER2-overexpressing breast cancers that also show increased cyclin $\mathrm{E}$ expression have lower 5 year disease-free survival versus those that have lower cyclin E levels (Mittendorf, 2010). Recently, cyclin E overexpression 
in HER2-overexpressing breast cancer cells that have acquired trastuzumab resistance was shown to be due to amplification of the cyclin E gene (Scaltriti, 2011). Amongst 34 patients with HER2-overexpressing breast cancer, cyclin E amplification was associated with worse response to trastuzumab (Scaltriti, 2011). Knockdown of cyclin E or cdk2 inhibition reduced proliferation and induced apoptosis of trastuzumab-resistant tumors (Scaltriti, 2011). Thus, cdk2 inhibition is a potential pharmacologic strategy for treating trastuzumab-resistant HER2-overexpressing breast cancers that show reduced p27kip1 or increased cyclin E levels.
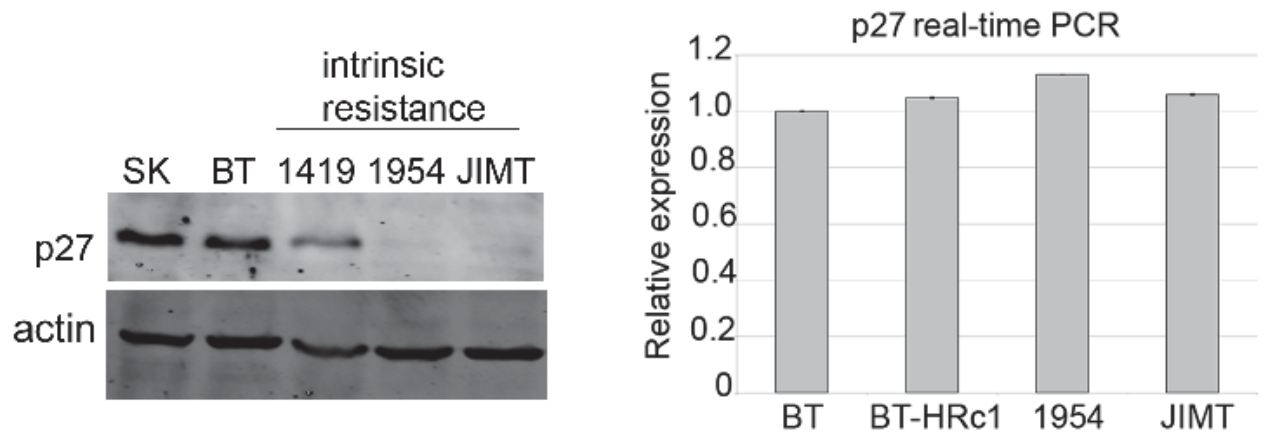

Fig. 4. p27 down-regulation in models of intrinsic (primary resistance). (A) SKBR3 and BT474 trastuzumab-sensitive cells and trastuzumab-resistant HCC1419, HCC1954, and JIMT-1 cells were examined by Western blotting for p27 and actin internal control. (B) BT474 and acquired resistant clone BT-HRc1 and primary resistant HCC1954 and JIMT-1 cells were examined by real-time PCR for p27 transcript which was normalized to RPLPO housekeeping gene.

\section{Combining multiple HER2-targeted agents in HER2-overexpressing breast cancer}

Two HER2-targeted agents are currently approved for use in the setting of metastatic HER2positive breast cancer, trastuzumab and lapatinib. These agents target HER2 via distinct mechanisms (Fig. 5). Trastuzumab is a monoclonal antibody that specifically recognizes and binds to an extracellular part of HER2. Since antibodies are large, bulky molecules, trastuzumab is unable to cross the blood-brain barrier and thus cannot combat brain metastases. In contrast, lapatinib is a small molecule kinase inhibitor targeted against the EGFR and HER2 active sites. Since it is a small molecule, it is believed that lapatinib has the potential to enter the brain and target metastatic cells that overexpress HER2. A phase II trial of lapatinib in patients with trastuzumab-refractory disease and CNS metastases showed some volumetric changes in brain lesions and improved neurologic symptoms (Lin, 2008; Lin, 2009). Amongst 50 patients who were terated with lapatinib plus capecitabine, $20 \%$ showed a CNS objective response and $40 \%$ experienced $20 \%$ or greater volumetric reduction in their CNS lesions (Lin, 2009), suggesting that lapatinib may have some utility in limiting CNS metastases of primary HER2-overexpressing breast cancers. 


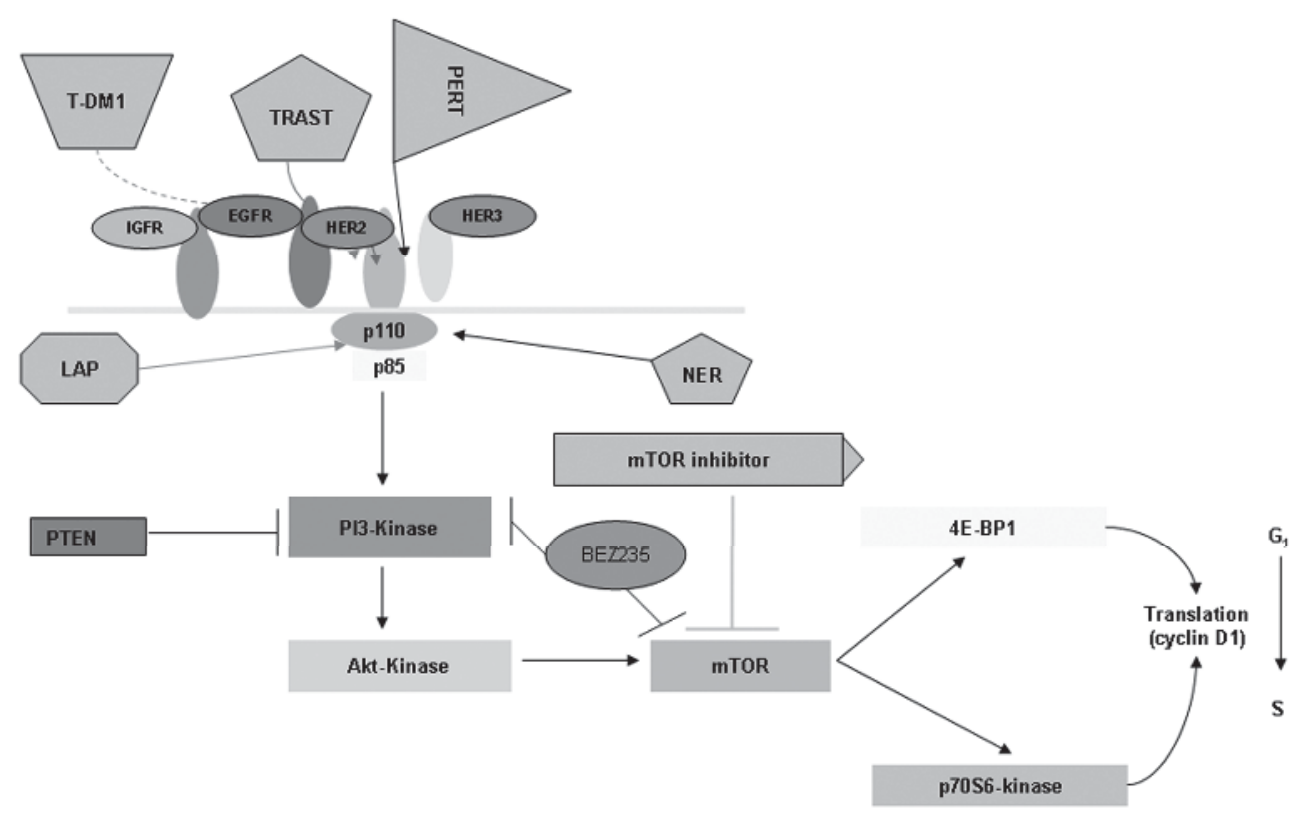

Fig. 5. Novel targeted agents in trastuzumab-resistant HER2-positive breast cancer. T-DM1, Trastuzumab-DM1; TRAST, Trastuzumab; PERT, Pertuzumab; IGFR, insulin growth factor receptor; EGFR, epidermal growth factor receptor; LAP, lapatinib; NER, neratinib.

\subsection{Combining trastuzumab with lapatinib}

Combination of trastuzumab plus lapatinib has been shown to induce apoptosis in part via down-regulation of survivin in cell culture and animal models (Xia, 2005). Initial phase I data suggested that the combination is well-tolerated and elicits partial or complete responses in a subset of patients who have progressed on prior trastuzumab therapy (Storniolo, 2008). The combination has been tested clinically in advanced phase trials in patients who have progressed on trastuzumab-based regimens. Progression-free survival and quality of life were improved in patients treated with the combination versus lapatinib alone (Wu, 2011). EGF104900 showed that the combination was superior to lapatinib alone in the trastuzumab-resistant setting, with a clonical benefit rate of $24.7 \%$ versus $12.4 \%$ (Blackwell, 2010). A potentially important mechanism of action of this drug combination is that lapatinib has been shown to induce accumulation of inactive HER2 dimers via reduced receptor ubiquitination, providing increased pharmacologic target for trastuzumabmediated antibody-dependent cellular cytotoxicity (Scaltriti, 2009). Combining trastuzumab with lapatinib offers a chemotherapy-free option for treating HER2-positive trastuzumabresistant disease.

\subsection{Combining trastuzumab with pertuzumab}

Pertuzumab is an anti-HER2 monoclonal antibody that targets an extracellular epitope distinct from what is targeted by trastuzumab. Pertuzumab binds to HER2 near the center of 
domain II, sterically blocking a binding pocket necessary for receptor dimerization and signaling (Franklin, 2004). In contrast, trastuzumab does not significantly inhibit HER2 interaction with other erbB receptors. We were the first to show that combining pertuzumab with trastuzumab results in synergistic inhibition of proliferation of HER2-overexpressing breast cancer cells (Nahta, 2004a). Trastuzumab increased pertuzumab-mediated disruption of HER2 dimerization with EGFR and HER3, and further reduced pertuzumab-mediated inhibition of PI3K signaling (Nahta, 2004a). Phase II data shows that combining trastuzumab with pertuzumab in patients who have progressed on prior trastuzumab regimens achieves clinical benefit rate of $50 \%$, objective response rates of $24 \%$, and median progression-free survival of 5. 5 months (Baselga, 2010a). A potential mechanism of synergy is nonoverlapping mechanisms by single agents, trastuzumab-mediated inhibition of p95HER2 cleavage and pertuzumab-mediated disruption of dimerization (Scheuer, 2009). Clinical evaluation of pertuzumab and trastuzumab (CLEOPATRA) is an international, randomized, double-blind, placebo-controlled phase III trial. Patients with HER2-positive breast cancer with locally recurrent or metastatic disease will be randomized to receive docetaxel, trastuzumab, and pertuzumab or docetaxel, trastuzumab, and placebo. Progresion-free survival will be assessed to determine efficacy of combination pertuzumab plus trastuzumab in the trastuzumab-refractory setting (Baselga, 2010b).

\section{Novel HER2-targeted agents in clinical development}

\subsection{Trastuzumab-DM1}

One novel preparation of trastuzumab is a drug conjugate called trastuzumab-DM1, which is trastuzumab conjugated to a microtubule-depolymerizing drug called maytansinoid (Lewis Phillips, 2008). Trastuzumab-DM1 blocks growth of trastuzumab-naive and trastuzumab-refractory HER2-overexpressing breast tumors in vivo (Lewis Phillips, 2008), and retains the mechanistic activity of unconjugated trastuzumab (Junttila, 2010). Antibodydependent cellular cytotoxicity was induced by trastuzumab-DM1, and tumor growth of trastuzumab-resistant cells was blocked by trastuzumab-DM1 due to induction of apoptosis and mitotic catastrophe (Barok, 2011). A phase I dose-escalation study in patients who had progressed on trastuzumab showed clinical benefit of $73 \%$ in 15 of 24 patients, including objective responses in 5 patients (Krop, 2010). A phase II study of trastuzumab-DM1 in patients with trastuzumab-refractory HER2-positive breast cancer showed objective response of $25.9 \%$ and median progression-free survival of 4.6 months (Burris, 2011). Thus, trastuzumab-DM1 HER2 antibody-chemotherapy conjugate is a promising treatment for HER2-positive breast cancer that has progressed on prior HER2-directed therapies.

\subsection{Irreversible pan-HER kinase inhibitors}

In contrast to lapatinib, which is a reversible EGFR/HER2 kinase inhibitor, irreversible panHER inhibitors are being developed for use against HER2-dependent breast cancers (Ocana, 2009). Neratinib, an irreversible EGFR/HER2 inhibitor, achieved a response rate of $26 \%$ in trastuzumab-pretreated patients and 55\% in trastuzumab-naïve patients (Burstein, 2009). Progression-free survival at 16 weeks was $60 \%$ and $77 \%$, respectively, for trastuzumabpretreated and naïve patients (Burstein, 2009). Finally, the median time to progression was 23 weeks and 40 weeks, respectively, for trastuzumab-pretreated and naïve patients (Burstein, 2009). Canertinib (CI-1033) is an irreversible inhibitor of all HER proteins. Response to canertinib was higher in patients with HER2-positive breast cancer, although toxicity at the most effective dose was limiting and unacceptable (Rixe, 2009). 


\section{Conclusion}

In conclusion, several major mechanisms of trastuzumab resistance have been proposed, including increased signaling from PI3K/mTOR, Src, and IGF-IR, as well as reduced p27kip1 and increased cdk2 activity. These mechanisms have uncovered new therapeutic targets for which multiple pharmacologic agents have been developed. Some of the most promising include mTOR-targeted agents derived from rapamycin and trastuzumab-DM1. Combining multiple HER2-targeted agents appears to be beneficial due to different mechanisms of action. Future studies should more clearly address the role of IGF-IR in acquired versus primary resistance, and test IGF-IR-targeted agents in combination with trastuzumab and/or lapatinib in a trastuzumab-refractory setting. In addition, studies examining the role of estrogen receptor (ER) signaling in trastuzumab resistant HER2positive ER-positive disease should be performed. Finally, biological predictors of response or resistance need to be developed to determine which patients are most likely to benefit from trastuzumab therapy, thus allowing for more specific individualization of targeted therapy in patients with HER2-overexpressing breast cancer.

\section{References}

Adams TE, Epa VC, Garrett TP, \& Ward CW. (2000). Structure and function of the type 1 insulin-like growth factor receptor. Cell Mol Life Sci, Vol. 57, No. 7, (July 2000), pp. 1050-93

Barok M, Tanner M, Koninki K, \& Isola J. (2011). Trastuzumab-DM1 causes tumor growth inhibition by mitotic catastrophe in trastuzumab-resistant breast cancer cells in vivo. Breast Cancer Res Vol. 13, No. 2, (2011 Apr 21), pp. R46

Baselga J, Tripathy D, Mendelsohn J, Baughman S, Benz CC, Dantis L, Sklarin NT, Seidman AD, Hudis CA, Moore J, Rosen PP, Twaddell T, Henderson IC, \& Norton L. (1996). Phase II study of weekly intravenous recombinant humanized anti-p185HER2 monoclonal antibody in patients with HER2/neu-overexpressing metastatic breast cancer. J Clin Oncol, Vol. 14, No. 3, (March 1996), pp. 737-44

Baselga J, Gelmon KA, Verma S, Wardley A, Conte P, Miles D, Bianchi G, Cortes J, McNally VA, Ross GA, Fumoleau P, \& Gianni L. (2010a). Phase II trial of pertuzumab and trastuzumab in patients with human epidermal growth factor receptor 2-positive metastatic breast cancer that progressed during prior trastuzumab therapy. J Clin Oncol Vol. 28, No. 7, (2010 Mar 1), pp. 1138-44

Baselga J \& Swain SM. (2010b). CLEOPATRA: a phase III evaluation of pertuzumab and trastuzumab for HER2-positive metastatic breast cancer. Clin Breast Cancer Vol. 10, No. 6, (2010 Dec 1), pp. 489-91

Berns K, Horlings HM, Hennessy BT, Madiredjo M, Hijmans EM, Beelen K, Linn SC, Gonzalez-Angulo AM, Stemke-Hale K, Hauptmann M, Beijersbergen RL, Mills GB, van de Vijver MJ, \& Bernards R. (2007). A functional genetic approach identifies the PI3K pathway as a major determinant of trastuzumab resistance in breast cancer. Cancer Cell Vol. 12, No. 4, (2007 Oct), pp. 395-402

Blackwell KL, Burstein HJ, Storniolo AM, Rugo H, Sledge G, Koehler M, Ellis C, Casey M, Vukelja S, Bischoff J, Baselga J, O'Shaughnessy J. (2010). Randomized study of Lapatinib alone or in combination with trastuzumab in women with ErbB2- 
positive, trastuzumab-refractory metastatic breast cancer. J Clin Oncol, Vol. 28, No. 7, (March 2010), pp. 1124-30

Burris HA 3rd, Rugo HS, Vukelja SJ, Vogel CL, Borson RA, Limentani S, Tan-Chiu E, Krop IE, Michaelson RA, Girish S, Amler L, Zheng M, Chu YW, Klencke B, \& O'Shaughnessy JA. (2011). Phase II study of the antibody drug conjugate trastuzumab-DM1 for the treatment of human epidermal growth factor receptor 2 (HER2)-positive breast cancer after prior HER2-directed therapy. J Clin Oncol Vol. 29, No. 4, (2011 Feb 1), pp. 398-405

Burstein HJ, Sun Y, Dirix LY, Jiang Z, Paridaens R, Tan AR, Awada A, Ranade A, Jiao S, Schwartz G, Abbas R, Powell C, Turnbull K, Vermette J, Zacharchuk C, \& Badwe R. (2010). Neratinib, an irreversible ErbB receptor tyrosine kinase inhibitor, in patients with advanced ErbB2-positive breast cancer. J Clin Oncol Vol. 28, No. 8, (2010 Mar 10), pp. 1301-7

Cardoso F, Durbecq V, Laes JF, Badran B, Lagneaux L, Bex F, Desmedt C, Willard-Gallo K, Ross JS, Burny A, Piccart M, \& Sotiriou C. (2006). Bortezomib (PS-341, Velcade) increases the efficacy of trastuzumab (Herceptin) in HER-2-positive breast cancer cells in a synergistic manner. Mol Cancer Ther Vol. 5, No. 12, (2006 Dec), pp. 304251

Carter P, Presta L, Gorman CM, Ridgway JB, Henner D, Wong WL, Rowland AM, Kotts C, Carver ME, \& Shepard HM. (1992). Humanization of an anti-p185HER2 antibody for human cancer therapy. Proc Natl Acad Sci U S A Vol. 89, No. 10, (1992 May 15), pp. 4285-9

Casalini P, Iorio MV, Berno V, Bergamaschi A, Børresen Dale AL, Gasparini P, Orlandi R, Casati B, Tagliabue E, \& Ménard S. (2007). Relationship between p53 and p2 7 expression following HER2 signaling. Breast, Vol. 16, No. 6, (December 2007), pp. 597-605

Chaves J, Saif MW. IGF system in cancer: from bench to clinic. (2011). Anticancer Drugs, Vol. 22, No. 3, (March 2011), pp. 206-12

Cobleigh MA, Vogel CL, Tripathy D, Robert NJ, Scholl S, Fehrenbacher L, Wolter JM, Paton V, Shak S, Lieberman G, \& Slamon DJ. (1999). Multinational study of the efficacy and safety of humanized anti-HER2 monoclonal antibody in women who have HER2-overexpressing metastatic breast cancer that has progressed after chemotherapy for metastatic disease. J Clin Oncol, Vol. 17, No. 9, pp. 2639-48

Cuello M, Ettenberg SA, Clark AS, Keane MM, Posner RH, Nau MM, Dennis PA, \& Lipkowitz S. (2001). Down-regulation of the erbB-2 receptor by trastuzumab (herceptin) enhances tumor necrosis factor-related apoptosis-inducing ligandmediated apoptosis in breast and ovarian cancer cell lines that overexpress erbB-2. Cancer Res, Vol. 61, No. 12, (June 2001), pp. 4892-4900

Eccles SA. (2001). The role of c-erbB-2/HER2/neu in breast cancer progression and metastasis. J Mammary Gland Biol Neoplasia Vol. 6, No. 4, (2001 Oct), pp. 393-406

Eichhorn PJ, Gili M, Scaltriti M, Serra V, Guzman M, Nijkamp W, Beijersbergen RL, Valero V, Seoane J, Bernards R, Baselga J. Phosphatidylinositol 3-kinase hyperactivation results in lapatinib resistance that is reversed by the 
mTOR/phosphatidylinositol 3-kinase inhibitor NVP-BEZ235. Cancer Res Vol. 68, No. 22, (2008 Nov 15), pp. 9221-30

Esparís-Ogando A, Ocaña A, Rodríguez-Barrueco R, Ferreira L, Borges J \& Pandiella A. (2008). Synergic antitumoral effect of an IGF-IR inhibitor and trastuzumab on HER2-overexpressing breast cancer cells. Ann Oncol, Vol. 19, No. 11, (November 2008) pp. 1860-9

Esteva FJ, Valero V, Booser D, Guerra LT, Murray JL, Pusztai L, Cristofanilli M, Arun B, Esmaeli B, Fritsche HA, Sneige N, Smith TL, \& Hortobagyi GN. (2002). Phase II study of weekly docetaxel and trastuzumab for patients with HER-2overexpressing metastatic breast cancer. J Clin Oncol, Vol. 20, No. 7 (2002 Apr 1), pp. $1800-8$

Franklin MC, Carey KD, Vajdos FF, Leahy DJ, de Vos AM, \& Sliwkowski MX. (2004). Insights into ErbB signaling from the structure of the ErbB2-pertuzumab complex. Cancer Cell Vol. 5, No. 4, (2004 Apr), pp. 317-28

Gajria D, \& Chandarlapaty S. (2011). HER2-amplified breast cancer: mechanisms of trastuzumab resistance and novel targeted therapies. Expert Rev Anticancer Ther, Vol. 11, No. 2, (February 2011), pp. 263-75

Geyer CE, Forster J, Lindquist D, Chan S, Romieu CG, Pienkowski T, Jagiello-Gruszfeld A, Crown J, Chan A, Kaufman B, Skarlos D, Campone M, Davidson N, Berger M, Oliva C, Rubin SD, Stein S, \& Cameron D. (2006). Lapatinib plus capecitabine for HER2-positive advanced breast cancer. N Engl J Med, Vol. 355, No. 26 (2006 Dec 28), pp. 2733-43.

Graus-Porta D, Beerli RR, Daly JM, \& Hynes NE. (1997). ErbB-2, the preferred heterodimerization partner of all ErbB receptors, is a mediator of lateral signaling. EMBO J, Vol. 16, No. 7, (April 1997), pp. 1647-55

Hankinson SE, Willett WC, Colditz GA, Hunter DJ, Michaud DS, Deroo B, Rosner B, Speizer FE, \& Pollak M. Circulating concentrations of insulin-like growth factor-I and risk of breast cancer. Lancet Vol. 351, No. 9113, (1998 May 9), pp. 1393-6.

Huang X, Qian X, Cheng C, He S, Sun L, Ke Q, Zhang L, Pan X, He F, Wang Q, Meng J, Ni R, \& Shen A. (2011). Expression of Pirh2, a p27(Kip1) ubiquitin ligase, in hepatocellular carcinoma: correlation with p27(Kip1) and cell proliferation. Hum Pathol, Vol. 42, No. 4, (April 2011), pp. 507-15

Jerome L, Alami N, Belanger S, Page V, Yu Q, Paterson J, Shiry L, Pegram M, \& LeylandJones B. (2006). Recombinant human insulin-like growth factor binding protein 3 inhibits growth of human epidermal growth factor receptor-2-overexpressing breast tumors and potentiates herceptin activity in vivo. Cancer Res Vol. 66, No. 14, (2006 Jul 15), pp. 7245-52

Jerusalem G, Fasolo A, Dieras V, Cardoso F, Bergh J, Vittori L, Zhang Y, Massacesi C, Sahmoud T, \& Gianni L. (2011). Phase I trial of oral mTOR inhibitor everolimus in combination with trastuzumab and vinorelbine in pre-treated patients with HER2overexpressing metastatic breast cancer. Breast Cancer Res Treat, Vol. 125, No. 2, (January 2011), pp. 447-55 
Jin Q \& Esteva FJ. (2008). Cross-talk between the ErbB/HER family and the type I insulinlike growth factor receptor signaling pathway in breast cancer. J Mammary Gland Biol Neoplasia, Vol. 13, No. 4, (December 2008), pp. 485-98

Junttila TT, Akita RW, Parsons K, Fields C, Lewis Phillips GD, Friedman LS, Sampath D, \& Sliwkowski MX. (2009). Ligand-independent HER2/HER3/PI3K complex is disrupted by trastuzumab and is effectively inhibited by the PI3K inhibitor GDC0941. Cancer Cell, Vol. 15, No. 5, (May 2009), pp. 429-40

Junttila TT, Li G, Parsons K, Phillips GL, \& Sliwkowski MX. (2010). Trastuzumab-DM1 (TDM1) retains all the mechanisms of action of trastuzumab and efficiently inhibits growth of lapatinib insensitive breast cancer. Breast Cancer Res Treat (2010 Aug 21. [Epub ahead of print])

Kalinsky K, Jacks LM, Heguy A, Patil S, Drobnjak M, Bhanot UK, Hedvat CV, Traina TA, Solit D, Gerald W, \& Moynahan ME. (2009). PIK3CA mutation associates with improved outcome in breast cancer. Clin Cancer Res, Vol. 15, No. 16, (August 2009), pp. 5049-59

Kotoshiba S, Kamura T, Hara T, Ishida N, \& Nakayama KI. (2005). Molecular dissection of the interaction between p27 and Kip1 ubiquitylation-promoting complex, the ubiquitin ligase that regulates proteolysis of p27 in G1 phase. J Biol Chem, Vol. 280, No. 18, (May 2005), pp. 17694-700

Krop IE, Beeram M, Modi S, Jones SF, Holden SN, Yu W, Girish S, Tibbitts J, Yi JH, Sliwkowski MX, Jacobson F, Lutzker SG, \& Burris HA. (2010). Phase I study of trastuzumab-DM1, an HER2 antibody-drug conjugate, given every 3 weeks to patients with HER2-positive metastatic breast cancer. J Clin Oncol Vol. 28, No. 16, (2010 Jun 1), pp. 2698-704

Lane HA, Motoyama AB, Beuvink I, \& Hynes NE. (2001). Modulation of p27/Cdk2 complex formation through 4D5-mediated inhibition of HER2 receptor signaling. Ann Oncol Vol. 12, Suppl 1, (2001), pp. S21-2.

Lang SA, Hackl C, Moser C, Fichtner-Feigl S, Koehl GE, Schlitt HJ, Geissler EK, \& Stoeltzing O. (2010). Implication of RICTOR in the mTOR inhibitor-mediated induction of insulin-like growth factor-I receptor (IGF-IR) and human epidermal growth factor receptor-2 (Her2) expression in gastrointestinal cancer cells. Biochim Biophys Acta, Vol. 4, (April 2010), pp. 435-42

Le XF, Claret FX, Lammayot A, Tian L, Deshpande D, LaPushin R, Tari AM, \& Bast RC Jr. (2003). The role of cyclin-dependent kinase inhibitor p27Kip1 in anti-HER2 antibody-induced G1 cell cycle arrest and tumor growth inhibition. J Biol Chem, Vol. 278, No. 26, (June 2003), pp. 23441-50

Lewis Phillips GD, Li G, Dugger DL, Crocker LM, Parsons KL, Mai E, Blättler WA, Lambert JM, Chari RV, Lutz RJ, Wong WL, Jacobson FS, Koeppen H, Schwall RH, KenkareMitra SR, Spencer SD, \& Sliwkowski MX. (2008). Targeting HER2-positive breast cancer with trastuzumab-DM1, an antibody-cytotoxic drug conjugate. Cancer Res Vol. 68, No. 22, (2008 Nov 15), pp. 9280-90

Liang K, Esteva FJ, Albarracin C, Stemke-Hale K, Lu Y, Bianchini G, Yang CY, Li Y, Li X, Chen CT, Mills GB, Hortobagyi GN, Mendelsohn J, Hung MC, \& Fan Z. (2010). Recombinant human erythropoietin antagonizes trastuzumab treatment of breast 
cancer cells via Jak2-mediated Src activation and PTEN inactivation. Cancer Cell Vol. 18, No. 5, (2010 Nov 16), pp. 423-35

Lin NU, Carey LA, Liu MC, Younger J, Come SE, Ewend M, Harris GJ, Bullitt E, Van den Abbeele AD, Henson JW, Li X, Gelman R, Burstein HJ, Kasparian E, Kirsch DG, Crawford A, Hochberg F, \& Winer EP. (2008). Phase II trial of lapatinib for brain metastases in patients with human epidermal growth factor receptor 2-positive breast cancer. J Clin Oncol Vol. 26, No. 12, (2008 Apr 20), pp. 1993-9

Lin NU, Diéras V, Paul D, Lossignol D, Christodoulou C, Stemmler HJ, Roché H, Liu MC, Greil R, Ciruelos E, Loibl S, Gori S, Wardley A, Yardley D, Brufsky A, Blum JL, Rubin SD, Dharan B, Steplewski K, Zembryki D, Oliva C, Roychowdhury D, Paoletti P, \& Winer EP. (2009). Multicenter phase II study of lapatinib in patients with brain metastases from HER2-positive breast cancer. Clin Cancer Res Vol. 15, No. 4, (2009 Feb 15), pp. 1452-9

Lu Y, Zi X, Zhao Y, Mascarenhas D, \& Pollak M. (2001). Insulin-like growth factor-I receptor signaling and resistance to trastuzumab (Herceptin). J Natl Cancer Inst, Vol. 93, No. 24, (December 2001), pp. 1852-7

Marches R, \& Uhr JW. (2004). Enhancement of the p27Kip1-mediated antiproliferative effect of trastuzumab (Herceptin) on HER2-overexpressing tumor cells. Int J Cancer, Vol. 112, No. 3, (November 2004), pp. 492-501

Miller TW, Forbes JT, Shah C, Wyatt SK, Manning HC, Olivares MG, Sanchez V, Dugger TC, de Matos Granja N, Narasanna A, Cook RS, Kennedy JP, Lindsley CW, \& Arteaga CL. (2009). Inhibition of mammalian target of rapamycin is required for optimal antitumor effect of HER2 inhibitors against HER2-overexpressing cancer cells. Clin Cancer Res, Vol. 15, No. 23, (December 2009), pp. 7266-76

Mitra D, Brumlik MJ, Okamgba SU, Zhu Y, Duplessis TT, Parvani JG, Lesko SM, Brogi E, \& Jones FE. (2009). An oncogenic isoform of HER2 associated with locally disseminated breast cancer and trastuzumab resistance. Mol Cancer Ther Vol. 8, No. 8, (2009 Aug), pp. 2152-62

Mittendorf EA, Liu Y, Tucker SL, McKenzie T, Qiao N, Akli S, Biernacka A, Liu Y, Meijer L, Keyomarsi K, \& Hunt KK. (2010). A novel interaction between HER2/neu and cyclin E in breast cancer. Oncogene Vol. 29, No. 27, (2010 Jul 8), pp. 3896-907

Molina MA, Codony-Servat J, Albanell J, Rojo F, Arribas J, \& Baselga J. (2001). Trastuzumab (herceptin), a humanized anti-Her2 receptor monoclonal antibody, inhibits basal and activated Her2 ectodomain cleavage in breast cancer cells. Cancer Res, Vol. 61, No. 12, (June 2001), pp. 4744-9

Nagata Y, Lan KH, Zhou X, Tan M, Esteva FJ, Sahin AA, Klos KS, Li P, Monia BP, Nguyen NT, Hortobagyi GN, Hung MC, \& Yu D. (2004). PTEN activation contributes to tumor inhibition by trastuzumab, and loss of PTEN predicts trastuzumab resistance in patients. Cancer Cell, Vol. 6, No. 2, (2004 Aug), pp. 117-27

Nahta R, Hung MC, \& Esteva FJ. (2004a). The HER-2-targeting antibodies trastuzumab and pertuzumab synergistically inhibit the survival of breast cancer cells. Cancer Res Vol. 64, No. 7, (2004 Apr 1), pp. 2343-6 
Nahta R, Takahashi T, Ueno NT, Hung MC, \& Esteva FJ. (2004b). P27(kip1) down-regulation is associated with trastuzumab resistance in breast cancer cells. Cancer Res, Vol. 64, No. 11, (June 2004), pp. 3981-6

Nahta, R, Yuan, L X, Zhang, Kobayashi, R, \& Esteva FJ. (2005). Insulin-like growth factor-i receptor/human epidermal growth factor receptor 2 heterodimerization contributes to trastuzumab resistance of breast cancer cells. Cancer Res, Vol. 65, No. 23, (Nov 2008), pp. 11118-28

Nielsen DL, Andersson M, \& Kamby C. (2008). HER2-targeted therapy in breast cancer. Monoclonal antibodies and tyrosine kinase inhibitors. Cancer Treat Rev, Vol. 35, No. 2, (April 2009), pp. 121-36

O'Brien NA, Browne BC, Chow L, Wang Y, Ginther C, Arboleda J, Duffy MJ, Crown J, O'Donovan N, \& Slamon DJ. (2010). Activated phosphoinositide 3-kinase/AKT signaling confers resistance to trastuzumab but not lapatinib. Mol Cancer Ther Vol. 9, No. 6, (June 2010), pp. 1489-502

Oakman C, Pestrin M, Zafarana E, Cantisani E, \& Di Leo A. (2010). Role of lapatinib in the first-line treatment of patients with metastatic breast cancer. Cancer Manag Res, Vol. 2, (January 2010), pp. 13-25

Ocaña A \& Amir E. (2009). Irreversible pan-ErbB tyrosine kinase inhibitors and breast cancer: current status and future directions. Cancer Treat Rev Vol. 35, No. 8, (2009 Dec), pp. 685-91

Rixe O, Franco SX, Yardley DA, Johnston SR, Martin M, Arun BK, Letrent SP, \& Rugo HS. (2009). A randomized, phase II, dose-finding study of the pan-ErbB receptor tyrosine-kinase inhibitor CI-1033 in patients with pretreated metastatic breast cancer. Cancer Chemother Pharmacol Vol. 64, No. 6, (2009 Nov), pp. 1139-48

Sachdev D, Singh R, Fujita-Yamaguchi Y, \& Yee D. (2006). Down-regulation of insulin receptor by antibodies against the type I insulin-like growth factor receptor: implications for anti-insulin-like growth factor therapy in breast cancer. Cancer, Vol. 66, No. 4, (February 2006), pp. 2391-402

Sakr RA, Barbashina V, Morrogh M, Chandarlapaty S, Andrade VP, Arroyo CD, Olvera N, \& King TA. (2010). Protocol for PTEN expression by immunohistochemistry in formalin-fixed paraffin-embedded human breast carcinoma. Appl Immunohistochem Mol Morphol Vol. 18, No. 4, (July 2010), pp. 371-4

Scaltriti M, Verma C, Guzman M, Jimenez J, Parra JL, Pedersen K, Smith DJ, Landolfi S, Ramon y Cajal S, Arribas J, \& Baselga J. (2009). Lapatinib, a HER2 tyrosine kinase inhibitor, induces stabilization and accumulation of HER2 and potentiates trastuzumab-dependent cell cytotoxicity. Oncogene Vol. 28, No. 6, (2009 Feb 12), pp. 803-14

Scaltriti M, Eichhorn PJ, Cortés J, Prudkin L, Aura C, Jiménez J, Chandarlapaty S, Serra V, Prat A, Ibrahim YH, Guzmán M, Gili M, Rodríguez O, Rodríguez S, Pérez J, Green SR, Mai S, Rosen N, Hudis C, \& Baselga J. (2011). Cyclin E amplification/overexpression is a mechanism of trastuzumab resistance in HER2+ breast cancer patients. Proc Natl Acad Sci U S A Vol. 108, No. 9, (2011 Mar 1), pp. 3761-6 
Scheuer W, Friess T, Burtscher H, Bossenmaier B, Endl J, \& Hasmann M. (2009). Strongly enhanced antitumor activity of trastuzumab and pertuzumab combination treatment on HER2-positive human xenograft tumor models. Cancer Res Vol. 69, No. 24, (2009 Dec 15), pp. 9330-6

Slamon DJ, Clark GM, Wong SG, Levin WJ, Ullrich A, \& McGuire WL. (1987). Human breast cancer: correlation of relapse and survival with amplification of the HER-2/neu oncogene. Science Vol. 235, No. 4785 (1987 Jan 9), pp. 177-82

Slamon DJ, Leyland-Jones B, Shak S, Fuchs H, Paton V, Bajamonde A, Fleming T, Eiermann W, Wolter J, Pegram M, Baselga J, \& Norton L. (2001) Use of chemotherapy plus a monoclonal antibody against HER2 for metastatic breast cancer that overexpresses HER2. N Engl J Med Vol. 15, No. 344, (March 2001), pp. 783-92

Sliwkowski MX, Lofgren JA, Lewis GD, Hotaling TE, Fendly BM, \& Fox JA. (1999). Nonclinical studies addressing the mechanism of action of trastuzumab (Herceptin). Semin Oncol Vol. 26, No. 4 Suppl 12, (1999 Aug), pp. 60-70

Spector NL \& Blackwell KL. (2009). Understanding the mechanisms behind trastuzumab therapy for human epidermal growth factor receptor 2-positive breast cancer. J Clin Oncol, Vol. 27. No. 34 (December 2009), pp. 5838-47

Storniolo AM, Pegram MD, Overmoyer B, Silverman P, Peacock NW, Jones SF, Loftiss J, Arya N, Koch KM, Paul E, Pandite L, Fleming RA, Lebowitz PF, Ho PT, \& Burris HA 3rd. (2008). Phase I dose escalation and pharmacokinetic study of lapatinib in combination with trastuzumab in patients with advanced ErbB2-positive breast cancer. J Clin Oncol Vol. 26, No. 20, (2008 Jul 10), pp. 3317-23

Surmacz E. (2000). Function of the IGF-I receptor in breast cancer. J Mammary Gland Biol Neoplasia, Vol. 5, No. 1 (January 2000), pp. 95-105

Van der Heijden, M S, \& Bernards, R. (2010). Inhibition of the PI3K pathway: Hope we can believe in? Clin Cancer Res, Vol. 16, No. 12 (June 2010), pp. 3094-9

Vermeulen K, Van Bockstaele DR, \& Berneman ZN. (2003). The cell cycle: a review of regulation, deregulation and therapeutic targets in cancer. Cell Prolif. Vol. 36, No. 3, (June 2003), pp. 131-49

Wu Y, Amonkar MM, Sherrill BH, O'Shaughnessy J, Ellis C, Baselga J, Blackwell KL, \& Burstein HJ. (2011). Impact of lapatinib plus trastuzumab versus single-agent lapatinib on quality of life of patients with trastuzumab-refractory HER2+ metastatic breast cancer. Ann Oncol (2011 Mar 15 [Epub ahead of print])

Wullschleger S, Loewith R, Oppliger W, \& Hall MN. (2005). Molecular organization of target of rapamycin complex 2. J Biol Chem, Vol. 280, No. 235, (September 2005), pp. 30697704

Xia W, Gerard CM, Liu L, Baudson NM, Ory TL, \& Spector NL. (2005). Combining lapatinib (GW572016), a small molecule inhibitor of ErbB1 and ErbB2 tyrosine kinases, with therapeutic anti-ErbB2 antibodies enhances apoptosis of ErbB2-overexpressing breast cancer cells. Oncogene Vol. 24, No. 41, (2005 Sep 15), pp. 6213-21

Yakes FM, Chinratanalab W, Ritter CA, King W, Seelig S, \& Arteaga CL. (2002). Herceptininduced inhibition of phosphatidylinositol-3 kinase and Akt Is required for antibody-mediated effects on p27, cyclin D1, and antitumor action. Cancer Res Vol. 62, No. 14, (2002 Jul 15), pp. 4132-41 
Yang XH, Flores LM, Li Q, Zhou P, Xu F, Krop IE, \& Hemler ME. (2010). Disruption of laminin-integrin-CD151-focal adhesion kinase axis sensitizes breast cancer cells to ErbB2 antagonists. Cancer Res Vol. 70, No. 6, (2010 Mar 15), pp. 2256-63

Zhang S, Huang WC, Li P, Guo H, Poh SB, Brady SW, Xiong Y, Tseng LM, Li SH, Ding Z, Sahin AA, Esteva FJ, Hortobagyi GN, \& Yu D. (2011). Combating trastuzumab resistance by targeting SRC, a common node downstream of multiple resistance pathways. Nat Med Vol. 17, No. 4, (2011 Apr), pp. 461-9 


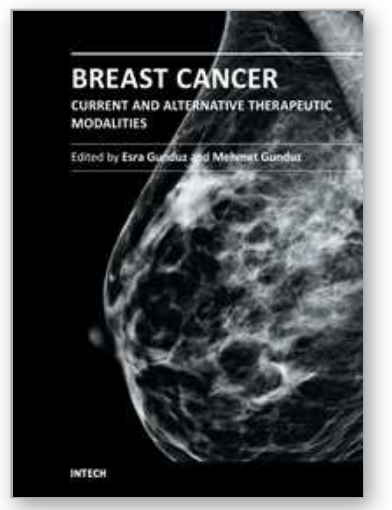

\author{
Breast Cancer - Current and Alternative Therapeutic Modalities \\ Edited by Prof. Esra Gunduz
}

ISBN 978-953-307-776-5

Hard cover, 540 pages

Publisher InTech

Published online 09, November, 2011

Published in print edition November, 2011

Cancer is the leading cause of death in most countries and its consequences result in huge economic, social and psychological burden. Breast cancer is the most frequently diagnosed cancer type and the leading cause of cancer death among females. In this book, we discussed various therapeutic modalities from signaling pathways through various anti-tumor compounds as well as herbal medicine for this deadly cancer. We hope that this book will contribute to the development of novel diagnostic as well as therapeutic approaches.

\title{
How to reference
}

In order to correctly reference this scholarly work, feel free to copy and paste the following:

Sylvia Shabaya and Rita Nahta (2011). Novel Therapeutic Strategies and Combinations for HER2-

Overexpressing Breast Cancer, Breast Cancer - Current and Alternative Therapeutic Modalities, Prof. Esra Gunduz (Ed.), ISBN: 978-953-307-776-5, InTech, Available from: http://www.intechopen.com/books/breastcancer-current-and-alternative-therapeutic-modalities/novel-therapeutic-strategies-and-combinations-for-her2overexpressing-breast-cancer

\section{INTECH}

open science | open minds

\section{InTech Europe}

University Campus STeP Ri

Slavka Krautzeka 83/A

51000 Rijeka, Croatia

Phone: +385 (51) 770447

Fax: +385 (51) 686166

www.intechopen.com

\section{InTech China}

Unit 405, Office Block, Hotel Equatorial Shanghai

No.65, Yan An Road (West), Shanghai, 200040, China

中国上海市延安西路 65 号上海国际贵都大饭店办公楼 405 单元

Phone: +86-21-62489820

Fax: +86-21-62489821 
(C) 2011 The Author(s). Licensee IntechOpen. This is an open access article distributed under the terms of the Creative Commons Attribution 3.0 License, which permits unrestricted use, distribution, and reproduction in any medium, provided the original work is properly cited. 